Eur J Clin Chem Clin Biochem

1995; 33:463-472

(c) 1995 Walter de Gruyter \& Co.

Berlin - Now York

\title{
Distribution' of Endothelin Receptor Subtypes in the Rat Kidney Renal and Haemodynamic Effects of the Mixed (A/B) Endothelin Receptor Antagonist Bosentan
}

\author{
By Berthold Hocher ${ }^{1,2}$, Peter Rohmeiss ${ }^{3}$, Fritz Diekmann ${ }^{1}$, Rüdiger Zart' ${ }^{2}$,Volker Vogt ${ }^{3}$, Sigrid Schiller ${ }^{4}$, \\ Christian Bauer ${ }^{2}$, Klaus Koppenhagen ${ }^{4}$, Armin Distler ${ }^{1}$ and Norbert Gretz ${ }^{3}$ \\ 1 Abteilung für Nephrologie, Universitätsklinikum Benjamin Franklin, Freie Universität Berlin, Berlin, Germany \\ 2 Institut für Molekularbiologie und Biochemie, Freie Universität Berlin, Berlin, Germany \\ ${ }^{3}$ Abteilung für Nephrologie, Klinikum Mannheim, Universität Heidelberg, Mannheim, Germany \\ ${ }^{4}$ Abteilung fïr Nuklearmedizin, Universitätsklinikum Benjamin Franklin, Freie Universität Berlin. Berlin, Germany'
}

(Received March 13/May 9, 1995)

Summary: The paracrine renal endothelin system has been implicated in acute and chronic kidney diseases. However, there are only few data about the cxpression of endothelin receptor subtypes and their impact on renal function in the normal rat kidney. Therefore, we analyzed the age-dependent expression of endothelin receptors (endothelin rcceptor A and B) using Scatchard analysis, in vitro and in vivo receptor autoradiography. Furthermore, we investigated the effects of the mixed (A/B) endothelin receptor antagonist bosentan on haemodynamic and renal function in conscious chronically instrumented rats. The renal endothelin receptor A and endothelin receptor B expression is age-dependent. The relative amount of endothelin receptor A significantly decreased with age, whereas the endothelin receptor $B$ significantly increased with age. Compared to the other renal structures, a high endothelin receptor density (endothelin receptor $B \gg$ endothelin receptor A) was seen in the renal tubules and even more in the glomeruli. Bosentan blocks both the pressor and depressor response of endothelin. Blocking of both endothelin receptor subtypes using bosentan without application of endothelin, on the other hand, did not alter blood pressure, heart rate, renal blood flow, water excretion or glomerular filtration rate, but significantly decreased sodium excretion.

\section{Introduction}

Endothelins (endothelin-1, endothelin-2 and endothelin3 ), a family of 21 amino acid peptides throught to regulate local vasomotor tone, are the most potent vasoconstrictor substances yet identified. Endothelin-1 was the first of the isopeptides to be characterized in the supernatant of cultured vascular endothelial cells (1). The biological effects of endothelin are mediated by plasmamembrane-bound receptors. Three endothelin receptor subtypes (endothelin receptor A, B and recently $C$ ) have been cloned $(2,3,4)$. Endothelin receptor $C$ has not yet been described in mammals. The endothelin receptors belong to the family of rhodopsin-like receptors with seven transmembrane domains coupled to a G-protein

and differ in their binding affinity to endothelin isopeptides (endothelin receptor $A$ : endothelin-1 $\geq$ endothelin$2 \gg$ endothelin-3; endothelin receptor B: endothclin-1 $=$ endothelin-2 $=$ cndothelin-3, endothelin receptor $\mathrm{C}$ : endothelin-3 $\gg$ endothelin-2 = endothelin-1) as well as in their expression by different cell types. In addition, there are indications that there are also nuclear endothelin receptors (5). Apart from possessing vasoactive properties, endothelins have been shown to cause a wide variety of biological activities in non-vascular tissues, including the kidney (6). The paracrine renal endothelin system has been implicatcd in pathogenesis of many diseases such as hypertension $(7,8)$ and impaired renal 
function in liver cirrhosis (9). Data from pharmacological studies indicate that renal blood flow and tubular function are partially controlled by both the endothelin receptor A and endothelin receptor B (10). However, little is known about the age-depedent expression, tissue distribution and physiology of endothelin receptor subtypes in the rat kidney. Therefore, the aim of our study was to analyze the age-dependent expression of endothelin receptor subtypes in the rat kidney using Scatchard analysis, in vitro and in vivo receptor autoradiography. Furthermore, we analyzed the effects of bosentan, an orally active, mixed (A/B) endothelin receptor antagonist (11), on mean arterial blood pressure, glomerular filtration rate, renal blood flow, heart rate and renal vascular resistance in conscious chronically instrumented rats. In addition, the effect of bosentan on water and sodium excretion was analyzed as well.

\section{Materials and Methods}

\section{Materials}

Male Wistar rats (WKY) were obtained from Møllegard, Denmark and fed a commercial diet (Altromin ${ }^{\circledR}$, Altromin GmbH, Germany) and were given water ad libitum. [ $\left.{ }^{125}\right]$ Endothelin-1 $(74 \mathrm{EBq} / \mathrm{mol}$ $=2000 \mathrm{Ci} / \mathrm{mmol}$ ) was obtained from Du Pont (Germany) ${ }^{32} \mathrm{P}$ dATP and ${ }^{35}$ S-UTP were from Amersham (Braunschweig, Germany). Unlabeled endothelin-1 was from Peninsula Laboratories, Inc. (Germany). The mixed (A/B) endothelin receptor antagonist bosentan (Ro 47-0203, 4-tert-butyl-N-[6-(2-hydroxy-ethoxy)-5-(2methoxy-phenoxy)-2,2'-bispyrimidine-4-yl]-benzenesulphonamide) was a generous gift from Dr. Martine Clozel, Pharma Division, F. Hoffmann-La Roche Ltd. (Basel, Switzerland). The selective endothelin receptor ligands (BQ 123 and BQ 3020) were from California Peptides Inc. (USA). Unless otherwise stated, all reagents were of analytical grade and were purchased from Merck (Darmstadt, Germany) Boehringer-Mannheim (Mannheim, Germany) or Sigma (Munich, Germany).

\section{Membrane preparation}

Membranes were prepared according to Nambi et al. (12). The rats were sacrificed, and the cortex and medulla were carefully dissected from each other. Approximately $150 \mathrm{mg}$ of kidney medulla or cortex were homogenized at $4^{\circ} \mathrm{C}$ in $10 \mathrm{ml}$ of $20 \mathrm{mmol} / \mathrm{l}$ $\mathrm{NaHCO}_{3}$ using a motor-driven pestle homogenizer. The homogenate was centrifuged at $4{ }^{\circ} \mathrm{C}$ for $15 \mathrm{~min}$ at $1000 \mathrm{~g}$. The supernatant was decanted and centrifuged at $4^{\circ} \mathrm{C}$ for $30 \mathrm{~min}$ at $40000 \mathrm{~g}$. The pellet consisting of crude plasma membranes was resuspended in assay buffer ( $1 \mathrm{~g} / \mathrm{l}$ bacitracin, $100 \mathrm{mmol} / \mathrm{T}$ Tris- $\mathrm{HCl}, 5 \mathrm{mmol} / \mathrm{l}$ $\mathrm{MgCl}_{2}$, and $1 \mathrm{~g} / \mathrm{l}$ bovine serum albumin, $\mathrm{pH}$ 7.4) at a protein concentration of $200 \mathrm{mg} / \mathrm{l}$.

\section{Binding assay for endothelin receptor A and B}

Binding studies were performed as previously described with some modifications (5). In order to analyze the expression of endothelin receptor subtypes (endothelin receptor $A$, endothelin receptor $B$ ) in the kidney, binding assays were performed in the presence or absence of the subtype-specific endothelin receptor ligands $B Q 123$ $(3 \mu \mathrm{mol} / \mathrm{l})$ and/or BQ 3020 (14). The assay buffer for binding studies contained $1 \mathrm{~g} / \mathrm{l}$ bacitracin, $100 \mathrm{mmol} / 1$ Tris- $\mathrm{HCl}, 5 \mathrm{mmol} / \mathrm{l}$ $\mathrm{MgCl}_{2}$, and $1 \mathrm{~g} / \mathrm{l}$ bovine serum albumin, $\mathrm{pH}$ 7.4. The total assay volume was $150 \mu \mathrm{l}$. The $\left.{ }^{[25} \mathrm{I}\right]$ endothelin-1 tracer concentration was kept constant at 40000 counts per minutes and tube, while the concentration of unlabeled endothelin- 1 was increased from 0 to $25 \mathrm{nmol} / 1$ (competition studies with "cold saturation"). Binding studies were performed at room temperature for $120 \mathrm{~min}$. Nonspecific binding was assessed in the presence of excess endothelin$1(5 \mu \mathrm{mol} / \mathrm{l})$. After adding $1 \mathrm{ml}$ of cold binding buffer, free and receptor-bound radioactivity was separated by centrifugation at $30000 \mathrm{~g}\left(4^{\circ} \mathrm{C}\right)$ for $15 \mathrm{~min}$, and the pellets thus obtained were washed two additional times with $1 \mathrm{ml}$ of cold binding buffer. ${ }^{125} \mathrm{I}$ was counted in a Packard Gamma Counter (78\% counting efficiency for ${ }^{125} \mathrm{I}$ ).

Autoradiography of tissue endothelin receptor subtypes

\section{In vivo autoradiography}

After anesthesia by intraperitoneal administration of pentobarbital, the vena cava inferior was cannulated. In order to block the endothelin receptor $A$, the endothelin receptor $B$ or both receptor subtypes BQ 123, BQ 3020 or BQ 123 and BQ 3020 (control) were injected into the vena cava inferior followed by an injection of $\left[{ }^{125}\right]$ endothelin-1 in saline $15 \mathrm{~min}$ thereafter. The dosages of endothelin-1, BQ 123 and BQ 3020 used did not alter the blood pressure during the experiment (data not shown). Fifteen min later the rats were sacrificed and the kidneys were perfused with $50 \mathrm{ml}$ of icecold saline, followed by fixation with $25 \mathrm{~g} / 1$ glutaraldehyde $/ 50 \mathrm{~g} / \mathrm{l}$ formalin. Thereafter the kidneys were removed and embedded in plastic material (Technovit ${ }^{\circledR}$, Kulzer GmbH, Germany). The plastic blocks were cut into $2.5-\mu \mathrm{m}$-thick sections, layered with photoemulsion (K5 nuclear trace emulsion, Ilford, England) and stained with hematoxylin and eosin. Evaluation was done by counting the silver grains. The number of silver grains in a given area was divided by the number of cell nuclei in the same area in order to consider possible differences in density of cells.

Contact autoradiography of tissue endothelin receptor subtypes was also performed. The kidneys were prepared as described above. The sections were apposed on X-ray film and exposed for 20-30 days under intensifying conditions.

\section{In vitro autoradiography}

The frozen kidneys were cut into $5 \mu \mathrm{m}$ thick sections with a microtome-cryostat. The sections were placed on precooled slides, airdried for $10 \mathrm{~min}$ and stored at $-20^{\circ} \mathrm{C}$. Autoradiographic incubation was performed in the presence or absence of subtype specific endothelin receptor ligands BQ $123(3 \mu \mathrm{mol} / \mathrm{l})$ and/or BQ 3020 $(3 \mu \mathrm{mol} / \mathrm{l})$. The slides were covered with $100 \mu \mathrm{l}$ binding buffer ( $1 \mathrm{~g} / \mathrm{l}$ bacitracin, $100 \mathrm{mmol} / 1$ Tris- $\mathrm{HCl}, 5 \mathrm{mmol} / \mathrm{l} \mathrm{MgCl}$, and $1 \mathrm{~g} / 1$ bovine serum albumin, $\mathrm{pH} 7.4$ ) containing [ ${ }^{125} \mathrm{I}$ ] endothelin-1 in a concentration of $50 \mathrm{pmol} / \mathrm{l}(4 \mathrm{MBq} / \mathrm{l})$ and incubated in a moist chamber for $2 \mathrm{~h}$ at room temperature. Radioactivity was withdrawn by suction with a vacuum pump and the slides were washed 4 times for $10 \mathrm{~min}$ in $4^{\circ} \mathrm{C}$ cold binding buffer. Finally the sections were fixed for $20 \mathrm{~min}$ in $50 \mathrm{~g} / \mathrm{l}$ formalin, $25 \mathrm{~g} / 1$ glutaraldehyde, $9 \mathrm{~g} / \mathrm{l} \mathrm{NaCl}$. To remove the salts the slides were dipped briefly in distilled water. Autoradiogramms with both endothelin receptor ligands (BQ 123, BQ 3020) served as a control. The sections were layered with photoemulsion (K5 nuclear trace emulsion, Ilford, England) and stained with hematoxylin and eosin. Evaluation was done by counting the silver grains.

\section{Contact autoradiography of tissue endothelin receptor subtypes}

The kidneys were prepared as described above. The sections were mounted on X-ray film and exposed for 2 days under intensifying conditions. 
Measurement of glomerular filtration rate, mean arterial blood pressure, heart rate and renal blood flow

\section{Surgical procedures}

One week prior to the acute experiments the rats were anaesthetized with ether and the femoral artery and vein catheters were implanted (3). Three'days before the start. of the experiments, flowprobes (1RB with implantable connector, Transsonic Systems Inc., lthaca, NY) were chronically implanted around the left renal artery. Briefly, the left kidney was exposed by a retroperitoneal access. The renal artery was carefully dissected using an operating microscope to avoid damage to the renal nerves. The flowprobe was then placed around the artery and, after the best signal had been achieved, the probe was fixed in proper position using a small envelope of Merocel Op-Wipe (Merocel Corp., Mystic, Connecticut, USA) covering the probe and the artery at the point of reflector attachment. To improve signal conductance, the envelope was filled with ultrasound gel. All catheters and cables were led subcutaneously to the rat's neck.

\section{Circulatory measurements}

Mean arterial blood pressure and heart rate were measured via the arterial line with a Statham pressure transducer $\mathrm{P} 23 \mathrm{Db}$ and a Gould pressure processor coupled to a Gould Brush 2600 recorder. Renal blood flow was measured via the chronically implanted flowprobe with a transit time flowmeter (T106, Transonic System Inc., Ithaca, NY, USA) and continuously recorded on a Gould Brush 2600 recorder. The Transonic flowmeter system determines absolute volume flow by measuring the difference (picosecond range) between the upstream and downstream time of flight of a wide beam of ultrasound across the blood vessel (14). The flowprobes were precalibrated by the producer and measured absolute blood flow with an accuracy of $\pm 2 \%$. Renal vascular resistance was calculated as mean arterial blood pressure divided by renal blood flow.

\section{Measurement of glomerular filtration rate}

Glomerular filtration rate was measured using the inulin singleshot method (15). The single-shot clearance was evaluated by displaying a two-compartment model with resolution of the plasma inulin concentrations into two monoexponential functions. The rats received an intravenous i.v. bolus injection of $150 \mathrm{mg}$ of inulin (Inutest ${ }^{\circledR}$ ). Blood samples for determination of serum inulin concentrations were drawn at $0,15,30,90,135$ and 180 minutes after injection. Inulin was measured by a modified $\beta$-fructosidase method (16). Glomerular filtration rate is expressed as $\mathrm{ml} / \mathrm{min}$ per $100 \mathrm{~g}$ body weight.

Effects of bosentan on the haemodynamic responses to endothelin

We tested the effects of increasing doses of the endothelin antagonist (bosentan or Ro 47-0203) on the haemodynamic responses to $200 \mathrm{ng}$ endothelin (i. v.) in 16-week-old Wistar Kyoto rats. The rats received i. v. bolus injections of $200 \mathrm{ng}$ endothelin 5 minutes after i.v. injections of vehicle. After baseline values had again been reached, the rats received increasing doses $(0.3,3,10,30$, and 100 $\mathrm{mg} / \mathrm{kg}$ ) of bosentan, five minutes prior i. v. bolus injections of 200 ng endothelin, respectively. Bosentan was dissolved in water at a concentration of $15 \mathrm{~g} / \mathrm{l}$. The highest volume needed for this study was $2 \mathrm{ml}$ and did not alter blood pressure, heart rate or renal blood flow jtself as shown by i.v. administration of vehicle. The animals were allowed to attain baseline values of all parameters measured between injections of endothelin with the respective endothelin antagonist. The conscious chronically instrumented rats received $200 \mathrm{ng}$ of endothelin- 1 and the doses $(0.3,3,10,30$, and $100 \mathrm{mg} / \mathrm{kg}$, respectively) of bosentan with breaks of 12 hours between the single experiments due to the well known tachyphylaxis after repeated injections of endothelin. Using this protocol we found no evidence for tachyphylaxis after repeated injections of endothelin with respect of blood pressure, renal blood flow and heart rate.

Effects of bosentan on glomerular filtration rate, mean arterial blood pressure, heart rate and renal blood flow

To examine the effects of bosentan on resting mean arterial blood pressure, heart rate, renal blood flow and renal vascular resistance in 16-week-old Wistar Kyoto rats, the rats received cumulative i. v. bolus injections of the mixed (A/B) endothelin receptor antagonist bosentan $(3 \mathrm{mg} / \mathrm{kg})$ every 15 minutes until a total load of $30 \mathrm{mg} /$ $\mathrm{kg}$ was obtained.

The experimental protocol for the determination of glomerular filtration rate was performed on two consecutive days. On day one 16-week-old male Wistar Kyoto rats received either an i.v. bolus injection of bosentan $(100 \mathrm{mg} / \mathrm{kg})$ or an i. v. bolus injection of vehicle $(0.3 \mathrm{ml} 9 \mathrm{~g} / 1 \mathrm{NaCl})$, followed by an i. v. bolus injection of $150 \mathrm{mg}$ inulin 5 minutes later. At $0,15,30,90,135$ and $180 \mathrm{~min}-$ utes after injection of inulin, blood samples $(200 \mu \mathrm{l})$ were taken from the arterial catheter for determination of serum inulin concentrations. On day two the animals underwent the same protocol but received bosentan instead of vehicle and vica versa.
Tab. 1 Receptor density and binding constants of endothelin receptor $A$ and endothelin receptor $B$ derived from $\left.{ }^{[25} I\right]$ endo- thelin-1 binding in the presence of the subtype-specific ligands to kidney membranes of 4- and 16-week-old Wistar Kyoto rats.

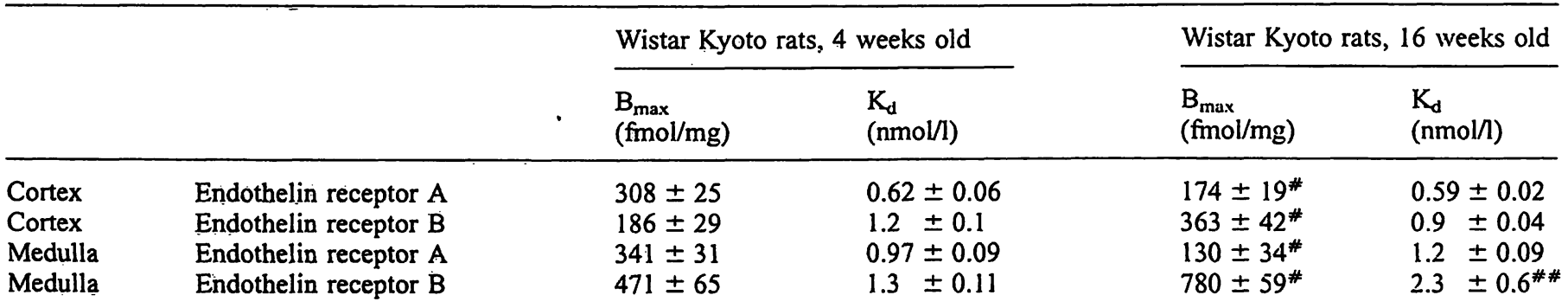

Data from Scatchard plots of $\left[{ }^{125} \mathrm{I}\right]$ endothelin-1 binding studies. To analyse expression of receptor subtypes, binding assays were performed in the presence of the subtype-specific ligands (BQ 123 or BQ 3020). Non-specific binding was assessed in the presence of $5 \mu \mathrm{mol} / 1$ of unlabeled endothelin-1. It ranges between $5-10 \%$.
For details see Material and Methods. Values are means $\pm S D$ of 6 separate animals in each group. $\left({ }^{*} \mathrm{p}<0.05\right.$ compared to the corresponding $B_{\max }$ in 4-week-old Wistar Kyoto rats, \#\# $<0.05$ compared to the corresponding $K_{d}$ in 4-week-old Wistar Kyoto rats. 


\section{Effects of bosentan on sodium and water excretion}

The rats were divided into three groups.

Group I: 8 control rats without bosentan treatment. The rats reccived vehicle ( $1.5 \mathrm{ml}$ suspension of $50 \mathrm{~g} / \mathrm{l}$ arabic gum) by gastric gavage at the hours $0,8,16$ for tivo days.

Group II: $\delta$ rats with bosentan treatment $(30 \mathrm{mg} / \mathrm{kg} \cdot \mathrm{d})$.

Group III: 8 rats with bosentan treatment $(100 \mathrm{mg} / \mathrm{kg} \cdot \mathrm{d})$.

Bosentan (micronized free sulphonamide) was used in suspension in $50 \mathrm{~g} / \mathrm{l}$ arabic gum (vehicle), prepared freshly and administered by gastric gavage with a polyethylene stomach tube (10 or 33.3 $\mathrm{mg} / \mathrm{kg}$ body weight in $1.5 \mathrm{ml}$ vehicle, respectively) by gastric gavage at the hours $0,8,16$ for two days. Urine was collected for the determination of sodium, potassium and volume.

\section{Results}

\section{Endothelin receptor binding experiments}

Scatchard analysis revealed only one type of endothelin receptor $A$ and $B$ binding sites (data not shown). The endothelin receptor $A$ and $B$ binding constants $\left(K_{d}\right)$ in the renal cortex were similar for 4- and 16-week-old Wistar Kyoto rats. On the other hand, the endothelin receptor $B$ binding constants $\left(K_{d}\right)$ in the renal medulla increased in an age-dependent manner (tab. 1).

The endothelin receptor $A$ density $\left(B_{\max }\right)$ in the whole kidney decreased with age, whereas the endothelin receptor $B$ density $\left(B_{\max }\right)$ increased with age $(p<0.05$ in all cases, tab. 1). The endothelin receptor $\mathrm{B} /$ endothelin receptor A ratio in the renal cortex is 0.60 in 4-weekold Wistar Kyoto rats and increased to 2.09 in 16-weekold Wistar Kyoto rats. The endothelin receptor B/endothelin receptor A ratio in the renal medulla is 1.38 in 4week-old Wistar Kyoto rats and increased to 6.00 in 16week-old Wistar Kyoto rats. These data are calculated from table 1 .

\section{Receptor autoradiography}

Non-specific binding was very low after blocking the endothelin receptors with BQ 123 and BQ 3020, as shown in figures 1-4. Receptor autoradiography showed that both subtypes (endothelin receptor A and endothelin receptor B) were present throughout the whole kidneys. Using in vivo autoradiography, the majority of binding sites in the kidney was observed in the cortex, mainly within the glomeruli. Both the endothelin receptor $A$ and the endothelin receptor $B$ were homogeneously distributed throughout the glomeruli (fig. 3). By counting the silver grains, we observed a $4.6 \pm 0.4$ fold increased density of endothelin receptor $B$ in the glomeruli $(n=6, p<0.01)$ compared to the density of endothelin receptor A in 16-week-old Wistar Kyoto rats, whereas the density of endothelin receptor A is 1.9 \pm 0.6 fold increased in the glomeruli of 4-week-old Wistar Kyoto rats $(n=6, p<0.05)$ compared to the density of endothelin receptor B (data not shown). Data concerning the expression of glomerular endothelin receptor subtypes obtained by in vivo or in vitro auto-

$1 \mathrm{a}$

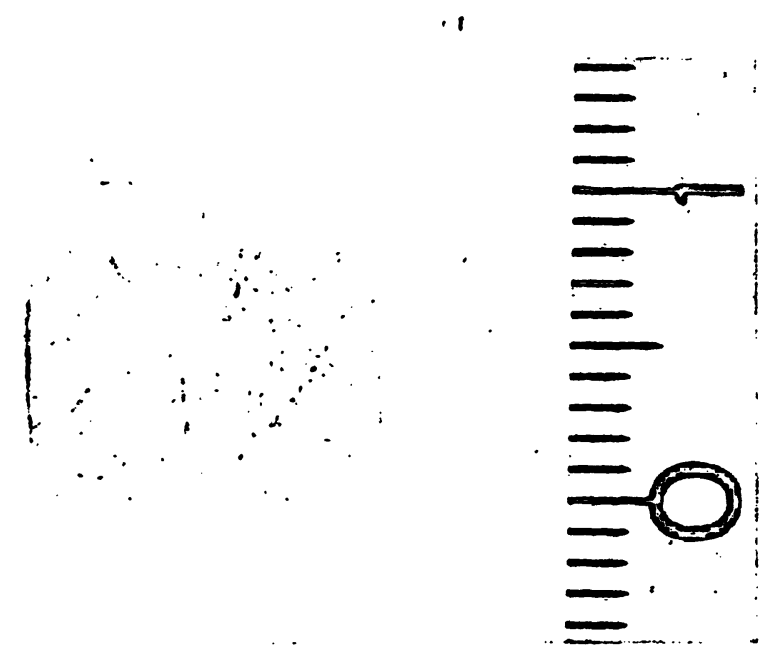

$1 \mathrm{~b}$
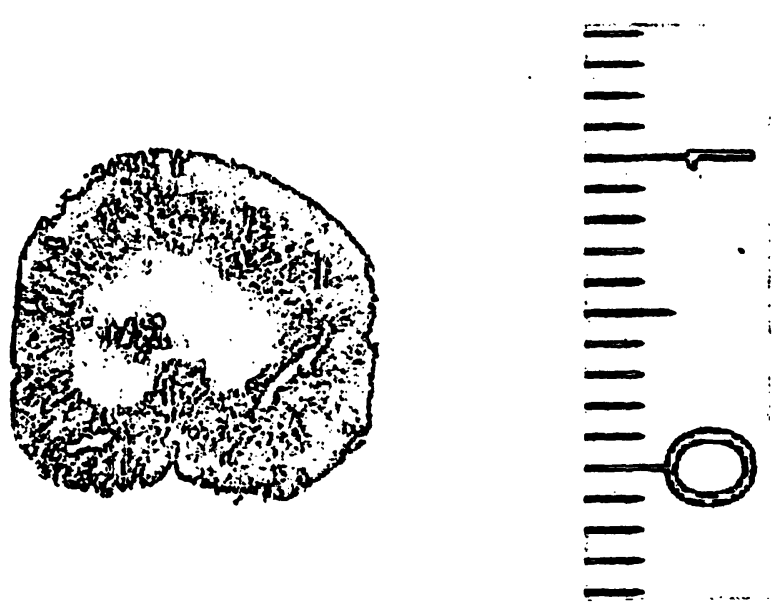

lc

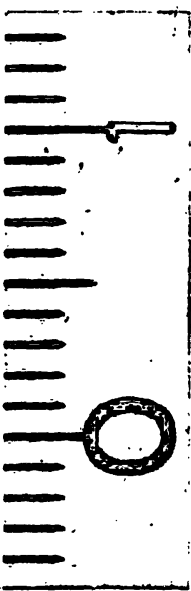

Fig. 1 Macroscopic in vitro autoradiography of endothelin receptor $A$ and endothelin receptor $B$ protein expression in the kidney of a 16-week-old Wistar Kyoto rat;

a) endothelin receptor A expression;

b) endothelin receptor B expression;

c) non-specific binding after blocking the endothelin receptor $A$ and endothelin receptor B with BQ 123 and BQ 3020 .

Magnification: $3 x$. 
radiography were equal. Contrary to the in vivo autoradiography, in vitro autoradiography revealed in high density of endothelin receptor B in medullary collecting ducts (figs. 1, 2) in 4 and moreover 16-week-old Wistar Kyoto rats. This was not an effect of length of tissue exposure to film, because in vivo and in vitro studies with a longer or shorter exposure time revealed the same differences.

$2 \mathrm{a}$

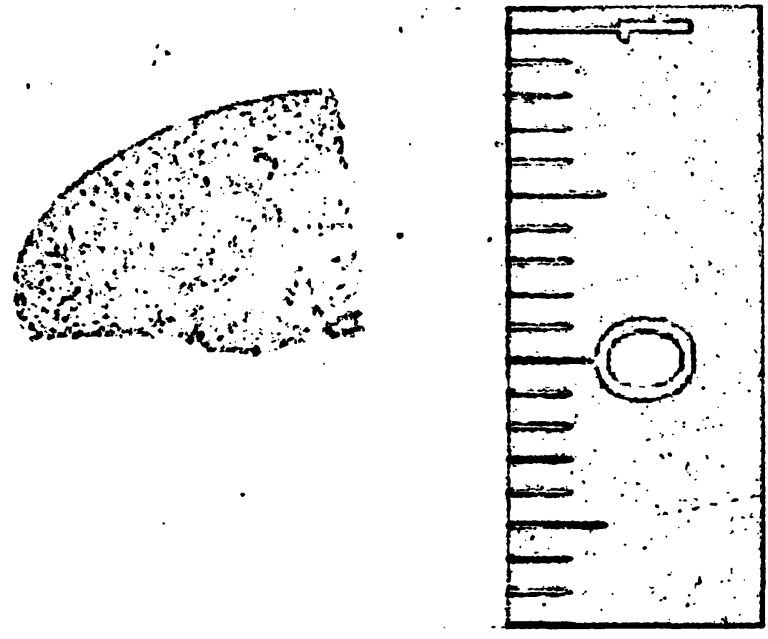

$2 b$
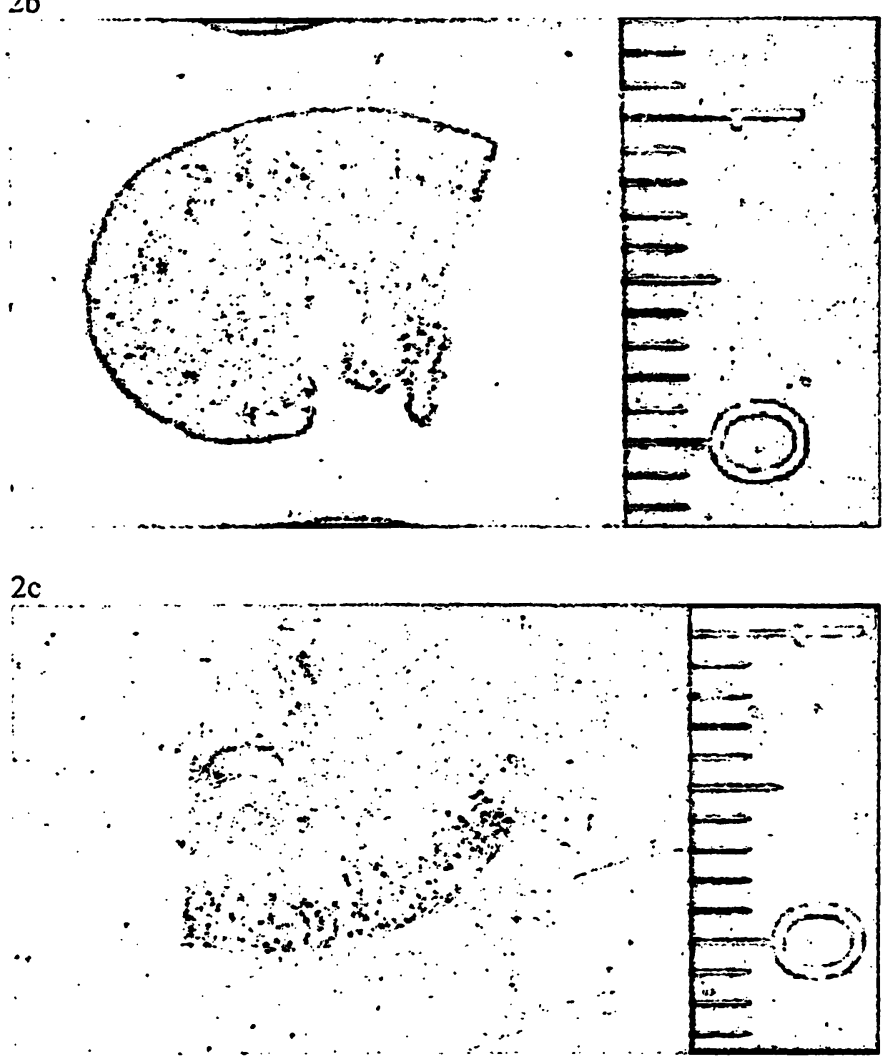

Fig. 2 Macroscopic in vivo autoradiography of endothelin receptor $A$ and endothelin receptor $B$ protein expression in the kidney of a 16-week-old Wistar Kyoto rat;

a) endothelin receptor $A$ expression;

b) endothelin receptor B expression;

c) non-specific binding after blocking the endothelin receptor $A$ and endothelin receptor B with BQ 123 and BQ 3020 .

Magnification: $3 \times$.
Effects of bosentan on the haemodynamic responses to endothelin

Intravenous bolus injections of 200 ng endothelin produced a biphasic blood pressor response: an initial shortlasting depressor effect was followed by a long-lasting blood pressure elevation. The changes in blood pressure were accompanied by reciprocal alterations in heart rate. In contrast, renal blood flow exhibited a monophasic response pattern (long-lasting decrease of renal blood flow) after endothelin i. v. Increasing doses of the endothelin antagonist induced a dose dependent blockade of the depressor effects to $200 \mathrm{ng}$ endothelin i. v., maximal blockade was achieved after $10 \mathrm{mg} / \mathrm{kg}$. Qualitatively the same was observed for the heart rate response during the depressor phase. In contrast, the pressor effect to endothelin i.v. was initially potentiated after increasing doses of the antagonist, with a maximum of potentiation after $3 \mathrm{mg} / \mathrm{kg}$. After the highest dose of the endothelin antagonist used in this study $(100 \mathrm{mg} / \mathrm{kg})$ the pressor effect was blocked by $89.7 \%$, whereas the heart rate response was blocked by $67.5 \%$. The effects of the endothelin antagonist on the changes in renal blood flow to endothelin i.v. were qualitatively and quantitatively similar to the effects on the pressor response, with a maximum of potentiation after $3 \mathrm{mg} / \mathrm{kg}$ and a maximal inhibition after $100 \mathrm{mg} / \mathrm{kg}$ of $92.5 \%$.

Effects of bosentan on renal blood flow, glomerular filtration rate, renal vessel resistance, heart rate and mean arterial blood pressure

Cumulative i. v. bolus doses ( $3 \mathrm{mg} / \mathrm{kg}$ every $15 \mathrm{~min}$ ) of the mixed $(\mathrm{A} / \mathrm{B})$ endothelin receptor antagonist did not alter renal blood flow, renal vessel resistance, heart rate or mean arterial blood pressure in 16-week-old Wistar Kyoto rats (fig. 8).

A bolus injection of the endothelin antagonist induced no alterations of glomerular filtration rate in 16-weekold Wistar Kyoto rats $(1.21 \pm 0.27$ versus $1.19 \pm 0.15$ $\mathrm{ml} / \mathrm{min}$ per $100 \mathrm{~g}$ body weight). The bolus injection of bosentan caused a minor, non-significant reduction of mean arterial blood pressure by $3.6 \pm 1.08 \mathrm{mmHg}$ in Wistar Kyoto rats.

\section{Effects of bosentan on water and sodium excretion}

The mixed $(\mathrm{A} / \mathrm{B})$ endothelin receptor antagonist bosen$\tan (100 \mathrm{mg} / \mathrm{kg} \cdot \mathrm{d}$ p. o. $)$ significantly $(\mathrm{p}<0.05)$ decreased sodium excretion in 16-week-old male Wistar Kyoto rats, whereas water excretion was not altered 
by bosentan (fig. 5). The effects after giving a lower dosage of bosentan $(30 \mathrm{mg} / \mathrm{kg}$. d) on water and sodium excretion were not different (as analyzed by impaired t-test, data not shown) from those obtained with the higher dosage $(100 \mathrm{mg} / \mathrm{kg} \cdot \mathrm{d})$, indicating that the lower dosage of bosentan also significantly $(p<0.05)$ decreased sodium excretion, whereas water excretion was not altered.
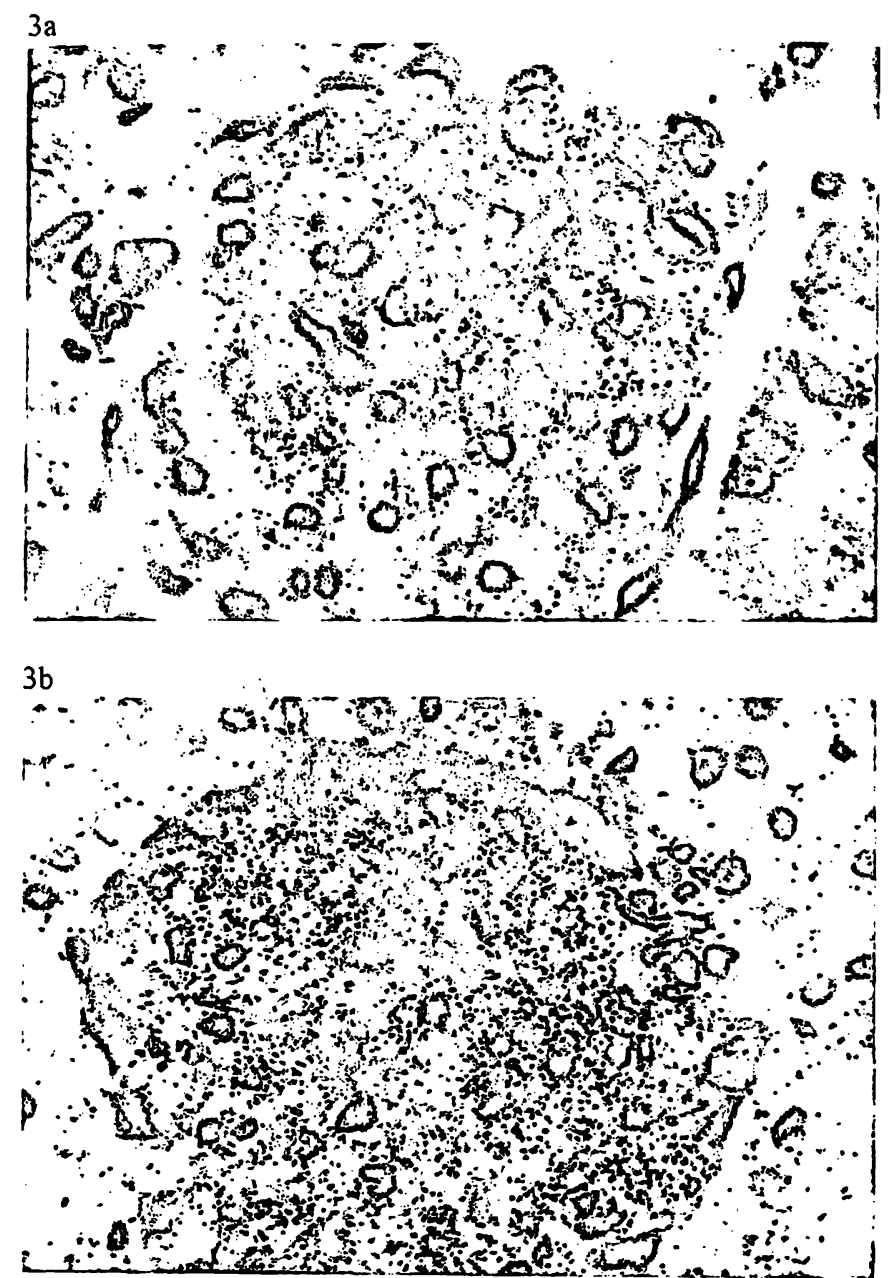

$3 \mathrm{c}$

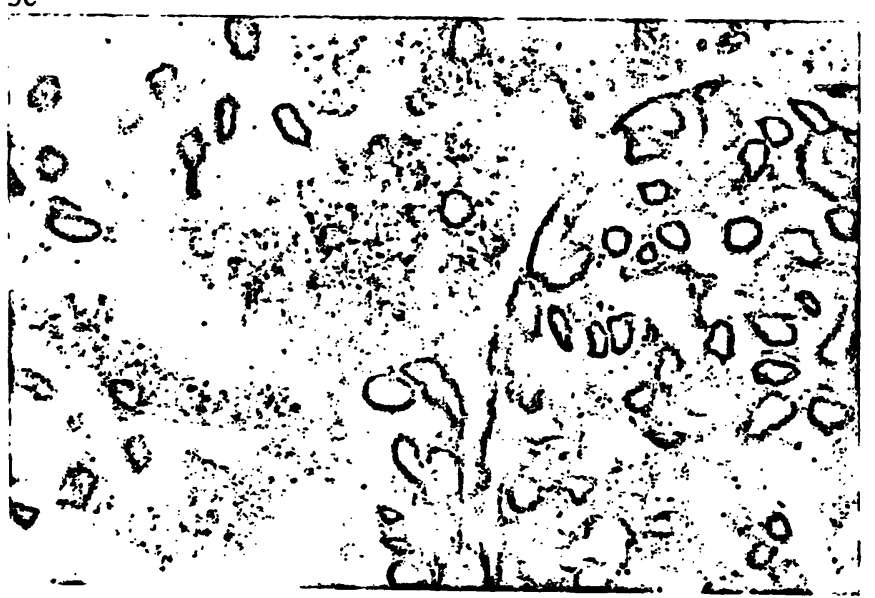

Fig. 3 Microscopic in vivo autoradiography of endothelin receptor $A$ and $B$ protein expression in the glomeruli of a 16-week-old Wistar Kyoto rat;

a) endothelin receptor $A$ expression;

b) endothelin receptor B expression;

c) non-specific binding after blocking the endothelin receptor $A$ and endothelin receptor B with BQ 123 and BQ 3020 Magnification: $555 \times$.
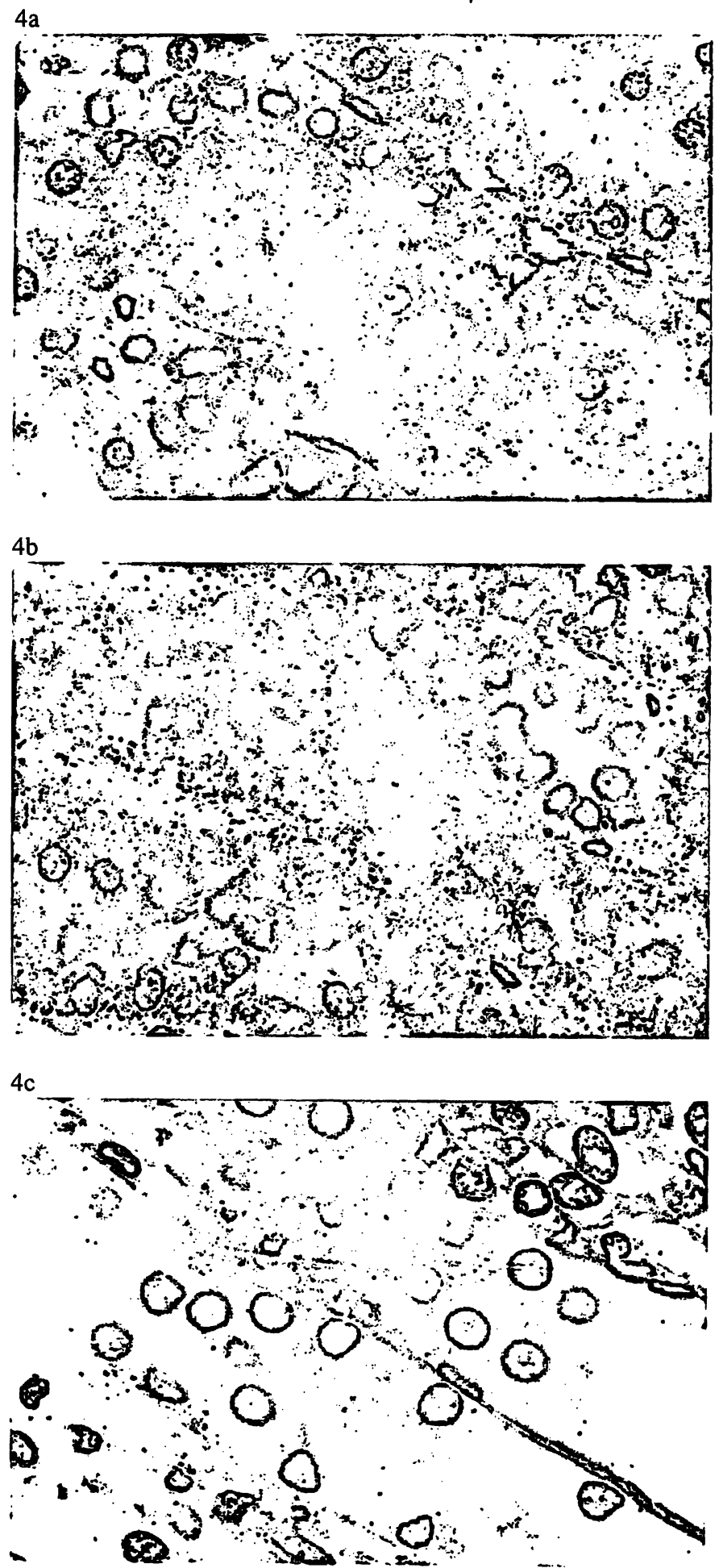

Fig. 4 Microscopic in vivo autoradiography of endothelin receptor $A$ and $B$ protein expression in the renal tubuli of a 16-weekold Wistar Kyoto rat;

a) endothelin receptor A expression;

b) endothelin receptor B expression;

c) non-specific binding after blocking the endothelin receptor $A$ and endothelin receptor B with $\mathrm{BQ} 123$ and $\mathrm{BQ} 3020$.

Magnification: $555 \times$. 

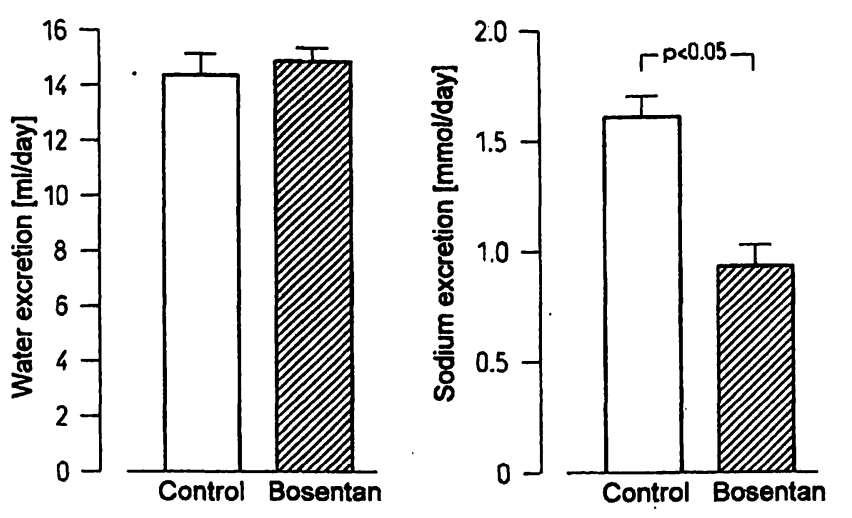

Fig. 5 The mixed (A/B) endothelin receptor antagonist bosentan decreased sodium excretion in 16-week-old Wistar Kyoto rats, whereas water excretion was not altercd by bosentan. Bosentan $(100 \mathrm{mg} / \mathrm{kg} \cdot \mathrm{d})$ or vehicle was given by gastric gavage $(n=8$; means $\pm \mathrm{SEM}$ ).

\section{Discussion}

Age-dependent differences in renal endothelin receptor expression

Binding studies showed that the endothelin receptor $\mathrm{B} /$ endothelin receptor A ratio in the kidney of Wistar Kyoto rats is age-dependent, suggesting age-dependent differences in the renal physiology of the paracrine endothelin system. Since it is well known that endothelin knock out mice have craniofacial abnormalities (17), our data might indicate (but does not prove) that age-dependent expression of endothelin receptor subtypes play a major role in the pre- and postnatal development of the rat kidney.

In addition, the endothelin receptor $\mathrm{B}$ binding constant in the renal medulla of Wistar Kyoto rats is also agedependent. We suggest that structural alterations of endothelin receptor B (phosphorylation or glycosylation) may occur with age. $\mathrm{N}$-glycosylation sites were identified in the outer cell domain of both endothelin receptor subtypes $(2,3)$.

\section{Receptor autoradiography}

The highest endothelin receptor density in the rat kidney was seen in the glomeruli using in vivo or in vitro autoradiography (fig. 3), whereas in the human kidney the highest endothelin receptor density was present within the renal blood vessels and medullary tubules as shown by Karet et al. (29) using in vitro receptor autoradiography. In comparison to the rat kidney (fig. 3) the glomeruli in the human kidney had a markedly lower density of endothelin receptors (29). However, the endothelin receptor $\mathrm{B} / \mathrm{endothelin}$ receptor $\mathrm{A}$ ratio in the kidney is similar in rats (tab. 1) and humans (29) as seen by Scatchard analysis.
The endothelin receptor B within the rat glomeruli seems to be located on the glomerular endothelial cells, as suggested by data from Furnuy et al. (18). Using electron microscopic autoradiography, they found that the endothelin-1 binding sites in the kidney were preferably localized on the fenestrated endothelial cells of glomeruli and peritubular capillary endothelial cells. The glomerular endothelin receptor $\mathrm{A}$ is most probably expressed by mesangial cells $(19,20)$.

On the other hand, our study clearly demonstrated different patterns of endothelin receptor subtype distribution in rat renal medulla depending on the method used (in vivo or in vitro autoradiography, figs. 1 and 2). Analyzing the total renal $\left[{ }^{125} \mathrm{I}\right]$ endothelin- 1 binding this phenomena was also seen by Koseki et al. (31). The reason for this discrepancy in our study and in the above mentioned study (31) between in vitro and in vivo receptor autoradiography is unknown, but there are two feasible explanations:

i) even very low concentrations of endothelin receptorligands may alter the renal microcirculation in vivo resulting in alterations of radioligand distribution or

ii) $\left[{ }^{125}\right]$ endothelin- 1 access to the tissues is not the same in vitro or in vivo due to the hydrophobic nature of the receptor ligands.

In any case in vivo receptor autoradiography seems to be a suitable method for preferential labeling of vascular endothelin receptors, whereas in vitro autoradiography labels both vascular and non-vascular endothelin receptors.

\section{Effects of bosentan on the haemodynamic responses to endothelin}

The mixed endothelin receptor antagonist bosentan was chosen for physiological studies, because this antagonist is orally active thus being of clinical relevance, whereas most of the selective yet described endothelin receptor $A$ and $B$ antagonists are not orally active. Due to the short supply of bosentan, our analysis was limited to 16week-old Wistar Kyoto rats. Bosentan is able to block in vivo both the pressor and depressor response to endothelin as shown in figure 6 and by others $(11,28)$, indicating that bosentan is an endothelin receptor $A$ and $B$ antagonist. However, in contrast to Gardiner et al. (28), our study revealed no effect of bosentan at a dosage of $30 \mathrm{mg} / \mathrm{kg}$ i. v. on the pressure response to $200 \mathrm{ng}$ endothelin-1 i.v. In our hands the endothelin-1 induced pressure effect was completely blocked only after $100 \mathrm{mg} /$ 

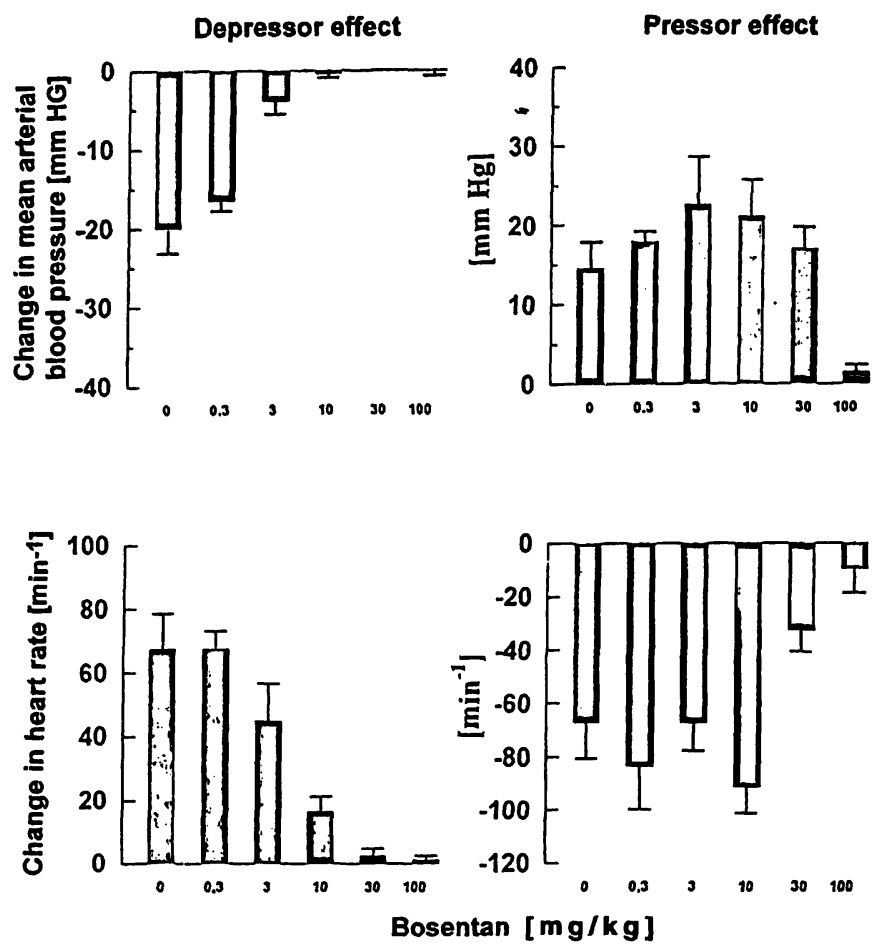

Fig. 6 Effects of increasing doses $(0,0.3,3,10,30$ and $100 \mathrm{mg} /$ $\mathrm{kg}$ ) of bosentan on the maximum changes in mean arterial blood pressure and heart rate during the depressor phase (left panel) and the pressor phase (right panel) after $200 \mathrm{ng}$ endothelin i.v. in 16week-old Wistar Kyoto rats. Data are represented as means + SEM.

$\mathrm{kg}$ bosentan (fig. 6), whereas the study of Gardiner et al. demonstrated a partial blockade of the endothelin-1 induced pressure effect after $30 \mathrm{mg} / \mathrm{kg}$ bosentan i.v. They suggested, but did not prove by a dose-dependent study, that the dose of bosentan used in their study (30 $\mathrm{mg} / \mathrm{kg}$ ) was insufficient to fully inhibit the haemodynamic effects of endothelin-1. In the present study we were able to demonstrate that the endothelin-1 induced pressure response was completely blocked after $100 \mathrm{mg}$ / $\mathrm{kg}$ bosentan i.v. (fig. 6). These minor differences concerning the bosentan dosage needed for complete blockage of the pressure response to endothelin-1 may be due to the different rat strains used in our study (Wistar Kyoto rats) and the study of Gardiner et al. (Long Evans rats).

The depressor response to endothelin is mediated by the endothelin receptor B-induced nitric oxide synthesis (21). Based on pharmacological studies using selective endothelin receptor A or B ligands, it was shown that the pressor response to endothelin-1 in rats is mediated by both the endothelin receptor A and B. Warner et al. (22) suggested the terms endothelin receptor Bl to describe the endothelin receptor B that mediates endothelium-dependent nitric oxide-induced vasorelaxation and endothelin receptor B2 to describe the endothelin receptor B that mediates vasoconstriction. However, several points should be addressed in this context:

i) Inhibition of the depressor response to endothelin-1 i.v. is achieved with relatively low doses of bosentan compared with those needed to block the pressor response to endothelin, probably because bosentan reaches effective local concentrations in the endothelin cells more easily than in the smooth muscle cells of the arteries.

ii) The pressor effect to endothelin i. v. was initially potentiated after increasing doses of bosentan. This observation may also reflect the above-mentioned higher local concentrations of bosentan in the endothelin cell layer than in the smooth muscle cells of blood vessels contributing to blood pressure, since the inhibitory effect of bosentan on the pressor effect is reduced by the concomitant inhibitors of the depressor effect. Only after having blocked all the endothelin receptor B (endothelin receptor B1), the net effect of bosentan resulted in lowering the mean arterial blood pressure.

iii) In contrast to systemic blood pressure and heart rate, renal blood flow exhibited a monophasic response pattern to endothelin (long-lasting decrease of renal blood flow without an initial increase of renal blood flow; fig. 7), suggesting that the endothelin receptor B1 mediated vasorelaxation is of minor importance or missing in the rat renal vascular beds.
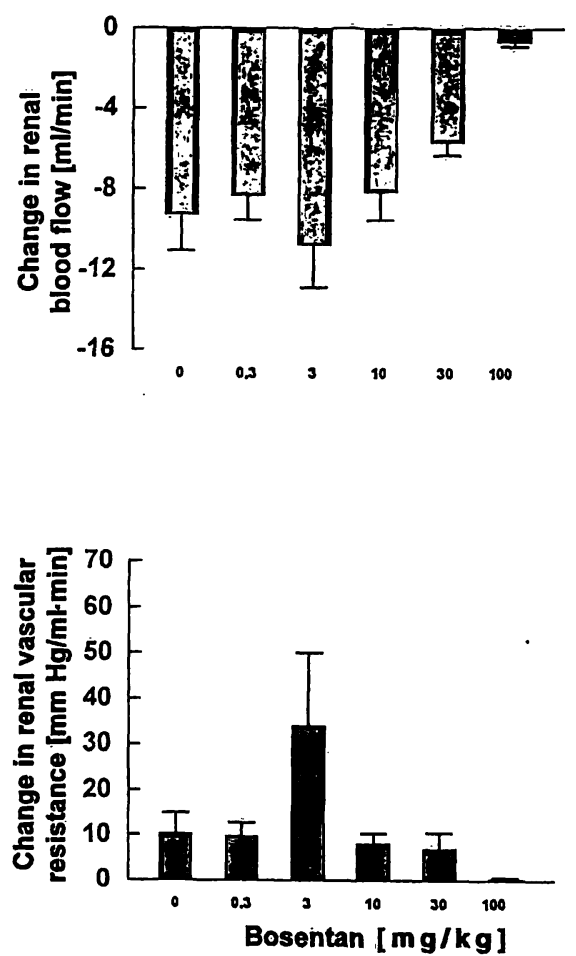

Fig. 7 Effects of increasing doses $(0,0.3,3,10,30$ and $100 \mathrm{mg}$ $\mathrm{kg}$ ) of bosentan on the maximum changes in renal blood flow and renal vascular resistance after $200 \mathrm{ng}$ endothelin i.v. in 16-weekold Wistar Kyoto rats. In contrast to the effects of bosentan on the maximum changes in blood pressure and heart rate, renal blood flow exhibited a monophasic response pattern. Data are represented as meåns + SEM. 


\section{Effects of bosentan on mean arterial blood pressure, heart rate, renal blood flow, glomerular filtration rate, water and sodium excretion in 16-week-old Wistar Kyoto rats}

In contrast to deoxycorticosterone acetate-salt hypertensive rats (23) or spontatneously hypertensive rats (24), bosentan does not alter mean arterial blood pressure, heart rate, renal blood flow or glomerular filtration rate in 16-week-old Wistar Kyoto rats (fig. 8), indicating that these parameters are not mainly controlled by the paracrine endothelin system in normotensive rats. It is also possible that the net effect of blocking both the endothelin receptor A and B resulted in no alterations of the above mentioned quantities. Therefore, subtype specific antagonists are necessary to answer this question. So-

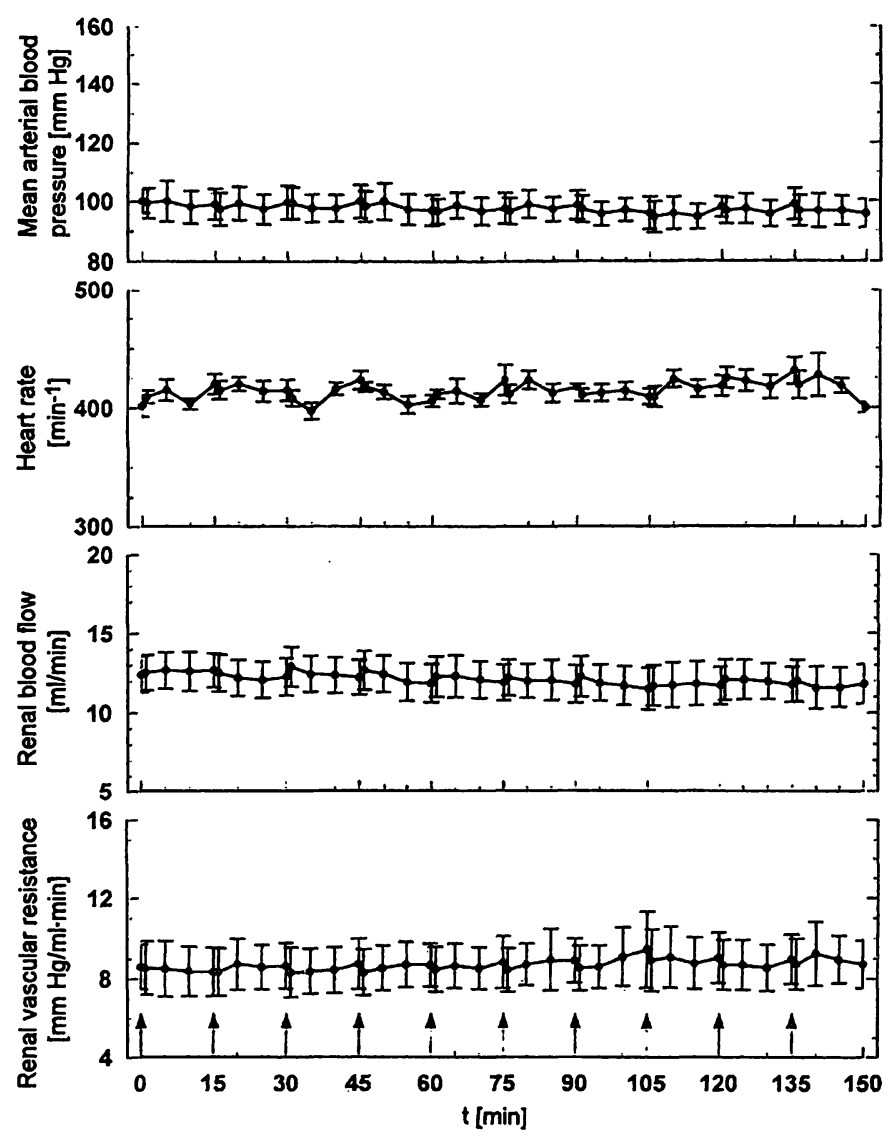

Fig. 8 Effects of cumulative i.v. bolus doses $(3 \mathrm{mg} / \mathrm{kg})$ of the endothelin antagonist bosentan on mean arterial blood pressure, heart rate, renal blood flow and renal vascular resistance in 16week-old male Wistar Kyoto rats. Arrows indicate time of injection (injection intervals: 15 minutes). Data are presented as means $\pm \mathrm{SEM}, \mathrm{n}=8$ ).

\section{References}

1. Yanagisawa M, Kurihara H, Kimura S, Tomobe Y, Kobayashi M, Mitsui Y, et al. A novel potent vasoconstrictor peptide produced by vascular endothelial cells. Nature 1988; 32(6163):411-5. dium excretion, on the other hand, is significantly reduced by the endothelin receptor antagonist bosentan, indicating that the tubular sodium transport in the renal medulla is under the control of the renal endothelin system. Our data are in agreement with studies showing an increased urinary sodium excretion caused by intravenous administration of endothelin receptor agonists (endothelin-1) (25). Some of these natriuretic effects of endothelin may be due to inhibition of sodium reabsorption in the renal collecting duct by action on both apical sodium entry and basolateral $\mathrm{Na}^{+} / \mathrm{K}^{+}$-ATPase $(26,27)$. Intravenous administration of endothelin- 1 or endothelin3 also reduces water reabsorption in the rat kidney (25). However, we did not see any effect on water excretion after blocking both the endothelin receptor $\mathrm{A}$ and $\mathrm{B}$ with bosentan, suggesting that the renal paracrine endothelin system in normotensive rats without exogenous stimulation plays a minor role in the regulation of water excretion, but is involved in the regulation of sodium excretion. The observed effects after intravenous endothelin administration on renal function $(25,26,27)$ most probably reflect the situation in an activated paracrine system and therefore are different from the situation without exogenous stimulation.

With respect to heart rate and blood pressure our data are in agreement with a recent report by Teerlink et al. (30). They also observed no significant changes in mean arterial blood pressure and heart rate in anesthetized open-chest dogs after blocking the endogenous endothelin system using bosentan.

In summary, this study showed that the renal endothelin receptor $\mathrm{A}$ and $\mathrm{B}$ expression is age-dependent. The relative amount of endothelin receptor A decreases significantly with age. The endothelin receptor B is the predominant endothelin receptor of the adult rat kidney. Compared to the other renal structures, a high endothelin receptor density (endothelin receptor A and B) was seen in the renal tubules and even more in the glomeruli. The mixed (A/B) endothelin receptor antagonist bosentan blocks both the pressor and depressor response of endothelin. Blocking of both endothelin receptor subtypes using bosentan without application of endothelin, on the other hand, did not alter blood pressure, heart rate, renal blood flow, water excretion and glomerular filtration rate, but significantly decreased sodium excretion.

2. Arai H, Hori S, Aramori L, Ohkubo H, Nakanishi S. Cloning and expression of a cDNA encoding an endothelin receptor. Nature 1990; 348(6303):730-2. 
3. Haendler B, Hechler U, Schleuning WD. Molecular cloning of human endothelin (ET) receptors ETA and ETB. J Cardiovasc Pharmacol 1992; 20 Suppl 12:S1 $\rightarrow 4$.

4. Kumar C, Mivangi V, Nuthulaganti P, Wu HL, Pullen M, Brun $\mathrm{K}$, et al. Cloning and characterization of a novcl endothelin receptor from Xenopus heart. J Biol Chem 1994; 269(18):1314-20.

5. Hocher B, Rubens C, Hensen J, Gross P, Bauer C. Intracellular distribution of endothelin-1 receptors in rat liver cells. Biochem Biophys Res Commun 1992; 184:498-503

6. Kohan DE. Endothelins in the kidney: physiology and pathophysiology. Am J Kidney Dis 1993; 22:493-510.

7. Gellai $M$, DeWolf $R$, Pullen $M$, Nambi P. Distribution and functional role of renal ET receptor subtypes in normotensive and hypertensive rats. Kidney Int 1994; 46:1287-94.

8. Lüscher TF, Seo BG, Bühler FR. Potential role of endothelin in hypertension. Controversy on endothelin in hypertension. Hypertension 1993; 21:752-7.

9. Asbert M, Gines A, Gines P, Jimenez W, Claria J, Salo J, et al. Circulating levels of endothelin in cirrhosis. Gastroenterology 1993; 104(5):1485-91.

10. Clozel M, Gray GA, Breu V, Löffler BM, Osterwalder R. The endothelin ETB receptor mediates both vasodilatation and vasoconstriction in vivo. Biochem Biophys Res Commun 1992; 186:867-73.

11. Clozel M, Breu V, Gray GA, Kalna B, Löffler BM, Burri K, et al. Pharmacological characterization of bosentan, a new potent orally active non-peptide endothelin receptor antagonist. J Pharmacol Exp Ther 1994; 270:228-35.

12. Nambi $P$, Pullen $M$, Contino LC. Upregulation of renal endothelin receptors in rats with cyclosporine A-induced nephrotoxicity. Eur J Pharmacol 1990; 187:113-6.

13. Rohmeiss $P$, Photiadis $J$, Rohmeiss $S$, Unger $T$. Hemodynamic actions of intravenous endothelin in the rat: comparison with sodium nitroprusside and methoxamine. Am J Physiol 1990; 258:H 337-H 46.

14. Drost C. Vessel-diameter independent volume flow measurements using ultrasound. Proc San Diego Biomed Symp., San Diego, USA 1978; 17:299-302.

15. Gretz N, Ecker-Tschirner KH, Kühnle HF, Dahl KV, Kirschfink $M$, Drescher $P$, et al. Practicability of the inulin plasma single-shot clearance. Contrb Nephrol 1990; 81:220-8.

16. Kuehnle HF, Dahl VD, Schmidt FH. Fully enzymatic determination in small volume samples without deproteinization. Nephron 1992; 62:104-7.

17. Kurihara $Y$, Kurihara $H$, Suzuki $H$, Kodama $T$, Maemura $K$, Nagal R, et al. Elevated blood pressure and craniofacial abnormalities in mice deficient in endothelin-1. Nature (London) 1994; 368:703-10.

18. Furuya S, Naruse S, Nakayama T, Nokihara K. Effect and distribution of intravenously injected ${ }^{125}$ I-endothelin-1 in rat kidney and lung examined by electron microscopic autoradiography. Anat Embryol (Berlin) 1992; 185(1):87-96.

19. Bakris GL, Re RN. Endothelin modulates angiotensin II-induced mitogenesis of human mesangial cells. Am J Physiol 1993; 264(6 Pt 2):F937-42.
20. Simonson MS, Herman W. Protein kinase $C$ and protein tyrosine kinase activity contribute to mitogenic signaling by endothelin-1. Cross-talk between $G$ protein-coupled receptors and pp60c-src. J Biol Chem 1993; 268(13):9347-57.

21. Hirata Y, Emori T, Eguchi S, Kanno K, Imai T, Ohta K, Marumo $\mathrm{F}$. Endothelin receptor subtype $\mathrm{B}$ mediates synthesis of nitric oxide by cultured bovine endothelial cells. J Clin Invest 1993; 91(4):1367-73.

22. Warner TD, Allcock GH, Micley EJ, Corder R, Vane J. Comparative studies with the endothelin receptor antagonists $B Q-$ 123 and PD-14293 indicate at least three endothelin receptors. J Cardiovasc Pharmacol 1993; 22(8 Suppl):S118-S20.

23. Li J, Lariviere, Rand Schiffrin L. Effect of a nonselective endothelin antagonist on vascular remodeling in deoxycorticosterone acetate-salt hypertensive rats. Hypertension 1994; 24:183-8.

24. Hocher B, Rohmeiss P, Zart R, Diekmann F, Vogt V, Metz D, et al. Expression of endothelin receptor subtypes in kidneys of spontaneously hypertensive rats; renal and hemodynamic effects of a mixed (A/B) endothelin receptor antagonist. Nieren und Hochdruckkrankheiten [abstract] 1994; 23:459.

25. Perico N, Cornejo RP, Benigni A, Malanchini B, Ladny JR, Remuzzi G. Endothelin induces diuresis and natriuresis in the rat by acting on proximal tubular cells through a mechanism mediated by lipoxygenase products. J Am Soc Nephrol 1991; 2:57-69.

26. Garvin J, Sanders K. Endothelin inhibits fluids and bicarbonate transport in part by reducing $\mathrm{Na}^{+} / \mathrm{K}^{+}$ATPase activity in the rat proximal straight tubule. J Am Soc Nephrol 1991; 2:976-86.

27. Harris PJ, Žhuo J, Mendelsohn FAO, Skinner SL. Haemodynamic and renal tubular effects of low doses of endothelin in anesthetized rats. J Physiol 1991; 433:25-39.

28. Gardiner SM, Kemp PA, March JE, Bennett T. Effects of bosentan (Ro 47-0203), an ETA-ETB receptor antagonist, on regional haemodynamic responses to endothelins in conscious rats. Br J Pharm 1994; 112:823-30.

29. Karet FE, Kuc RE, Davenport AP. Novel ligands BQ 123 and BQ 3020 characterize endothelin receptor subtypes ETA and ETB in human kidney. Kidney Int 1993; 44:36-42.

30. Teerlink JR, Carteau JP, Sprecher U, Löffler BM, Clozel M, Clozel JP. Role of endogenous endothelin in normal hemodynamic status of anesthetized dogs. Am J Physiol 1995; 268:H432-H40.

31. Koseki C, Imai M, Hirata Y, Yanagisawa M, Masaki T. Autoradiographic distribution in rat tissues of binding sites for endothelin: a neuropeptide? Am J Physiol 1989; 256:R858-R66.

Dr. Berthold Hocher
Universitätsklinikum Benjamin Franklin
Freie Universität Berlin
Abteilung für Innere Medizin
Hindenburgdamm 30
D-12200 Berlin
Germany

